\title{
Sweden: Financial Sector Assessment Program Update-Technical Note on Reviewing the Systemic Liquidity Risk Management Framework
}

This technical note on Reviewing the Systemic Liquidity Risk Management Framework was prepared by a staff team of the International Monetary Fund as background documentation for the periodic consultation with the member country. It is based on the information available at the time it was completed in September, 2011. The views expressed in this document are those of the staff team and do not necessarily reflect the views of the government of Sweden or the Executive Board of the IMF.

The policy of publication of staff reports and other documents by the IMF allows for the deletion of market-sensitive information.

Copies of this report are available to the public from

International Monetary Fund • Publication Services

$70019^{\text {th }}$ Street, N.W. • Washington, D.C. 20431

Telephone: (202) 623-7430 • Telefax: (202) 623-7201

E-mail: publications@imf.org Internet: http://www.imf.org

\section{International Monetary Fund Washington, D.C.}


FinANCIAL SECTOR ASSESSMENT PROGRAM UPDATE

\section{SWEDEN}

REVIEWING THE SYSTEMIC LIQUIDITY RISK MANAGEMENT FRAMEWORK

\section{TECHNICAL NOTE}

SEPTEMBER 2011

INTERNATIONAL MONETARY FUND

Monetary ANd CAPITAL MARKETS DePARTMENT 
Glossary 3

I. Introduction 4

II. The Global Financial Crisis: Sweden's Experience ..................................................4

A. The Buildup of Systemic Liquidity Risks in the Swedish Financial System...........4

B. Sweden's Response to Severe Funding Stress and Key Lessons ............................5

III. Strengthening the Systemic Liquidity Risk Management Framework ...........................10

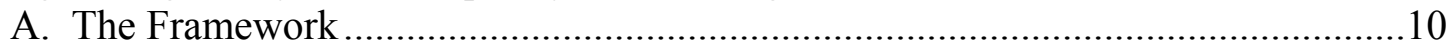

B. Liquidity Regulation .............................................................................. 12

C. The Framework for Foreign Exchange Liquidity Support..................................14

D. The Riksbank’s Domestic Liquidity Management Framework ............................17

Tables

1. Selected Economies: Central Banks' Liquidity Strain Easing Measures ...........................9

2. Alternative Approaches in Reviewing International Reserve Management.....................17

Figures

1. Build Up of Systemic Liquidity Risks Prior to the Crisis...............................................6

2. Decomposition of Three Month Interbank Rates............................................................

3. Selected Central Banks .........................................................................................

4. The Outstanding of Riksbank Loans and Government Guaranteed Debt..........................8

5. Central Bank Balance Sheets ..................................................................................18

6. Comparisons of Riksbank's and Federal Reserve's Balance Sheet Structure ..................18

Boxes

1. Regulation on Management of Liquidity Risks in Credit Institutions

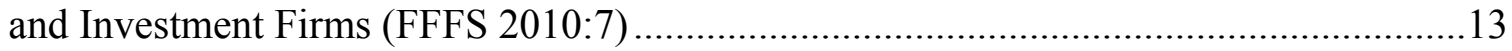

2. Major Swedish Banks — Unique and Diversified Business Models ................................14

3. International Practice: Arrangements for International Reserve Management.................16

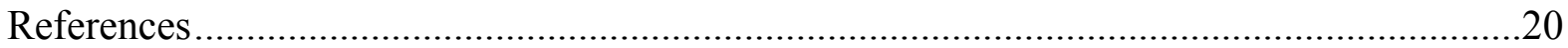




\section{GLOSSARY}

$\begin{array}{ll}\text { BoK } & \text { Bank of Korea } \\ \text { ECB } & \text { European Central Bank } \\ \text { EU } & \text { European Union } \\ \text { FSA } & \text { Financial Supervisory Authority } \\ \text { FSAP } & \text { Financial Sector Assessment Program } \\ \text { LCR } & \text { Liquidity Coverage Ratio } \\ \text { MoF } & \text { Ministry of Finance } \\ \text { MoFE } & \text { Ministry of Finance and Economy } \\ \text { NDO } & \text { National Debt Office } \\ \text { NSFR } & \text { Net Stable Funding Ratio }\end{array}$




\section{INTRODUCTION ${ }^{1}$}

1. Swedish banks faced a severe liquidity strain in the autumn of 2008, when global funding markets were impaired following the collapse of Lehman Brothers. The vulnerability of these banks to liquidity shocks reflected, in part, their extensive reliance on global wholesale funding. As the global crisis worsened, the authorities implemented aggressive stabilization measures, which helped to successfully contain the financial instability risks that had emerged.

2. However, the experience of the crisis revealed some weaknesses in the existing systemic liquidity risk management framework in Sweden. In particular, the liquidity regulations in place before the crisis, including the regulatory reporting framework, proved ineffective. There was also some ambiguity in regard to the institutional arrangements for international reserve management. Furthermore, given the leanness of its balance sheet structure, the Riksbank faced constraints in flexibly implementing some liquidity easing measures, such as a securities lending facility.

3. The main objective of this note is to elaborate on the recommendations made in the Financial Sector Assessment Program (FSAP) Update in the area of systemic liquidity risk management. Systemic liquidity risk can be broadly defined as the risk of simultaneous liquidity difficulties faced by multiple financial institutions (IMF, 2011). Among the various dimensions of liquidity risk, this note focuses on funding liquidity risk - the risk that an institution will not be able to meet expected cash flow requirements by raising funds on short notice- because this was the most relevant dimension of liquidity risk that the Swedish financial system faced during the global crisis. Furthermore, this note does not cover a range of issues on emergency liquidity assistance to individual institutions. Section II briefly discusses Sweden's experience of the global financial crisis. Section III reviews Sweden's systemic liquidity risk management framework with reference to the four pillars of a robust framework, and provides recommendations on relatively weak areas, namely: liquidity regulations, international reserve management policy, and some aspects of the Riksbank's domestic liquidity toolkit.

\section{The Global Financial CRisis: SWeden's ExPERIEnCE}

\section{A. The Buildup of Systemic Liquidity Risks in the Swedish Financial System}

Systemic liquidity risks built up in the years leading up to the global crisis (Figure 1).

4. Since the early 2000s, Swedish banks have increasingly relied on global wholesale funding to support expansion in their credit operations. As the pace of credit demand outpaced that of deposits, Swedish banks increased their issuance of debt in global markets, and

\footnotetext{
${ }^{1}$ This Technical Note was prepared by Kotaro Ishi.
} 
by 2008, the share of banks' funding through non-deposit sources reached nearly half of their lending. ${ }^{2}$ Although this trend coincided to some extent with European Union (EU)-wide developments, major Swedish banks' dependence on wholesale funding exceeded that of most European peers.

5. Part of this trend can be accounted for by the following factors. First, major Swedish banks have sought business opportunities abroad, mainly in the Nordic and Baltic regions, partly reflecting saturation in domestic markets. As a result, Swedish banks increased their foreign assets, which have more than doubled over the last decade, reaching 150 percent of GDP by 2008 (IMF 2010a). Second, housing markets continued to boom, and so did demand for mortgages, even during the recent global crisis. Meanwhile, the cost of funding in U.S. dollar markets has been cheaper than alternative means of funding; this drove Swedish banks to increase their dollar funding, by swapping part of these dollars for Swedish kroner and lending to the Swedish housing sector. The covered bond market reform of 2004 also contributed to Swedish banks' increased reliance on wholesale funding.

6. A substantial portion of wholesale funding is in shorter terms. As of end-2008, about 15 percent of total outstanding bonds were estimated to fall due within one year, and, in total, about 20-25 percent within two years. Accordingly, the Swedish banking system was exposed to large refining risks in the middle of the global financial crisis.

\section{B. Sweden's Response to Severe Funding Stress and Key Lessons}

\section{The Swedish banking system was seriously affected by the global financial crisis}

7. Several Swedish banks experienced difficulty in rolling over their debt obligations, particularly after the collapse of Lehman Brothers in September 2008. This was evidenced by a sharp increase in the risk premium in the Swedish interbank markets. With increased counterparty risks, funding markets (both local and foreign currencies), as well as currency swap markets, were impaired, as banks tended to hoard liquidity, resulting in a systemic liquidity shortage.

\footnotetext{
${ }^{2}$ In part, this trend reflects a structure change in the flow of funds in Sweden. Particularly, in recent years, the household sector increased investment in non-deposits, such as institutional pension funds, and these institutional funds have in turn become important large fund suppliers in the financial system.
} 
Figure 1. Sweden: Build Up of Systemic Liquidity Risks Prior to the Crisis

Banks reliance on deposit funding declined...

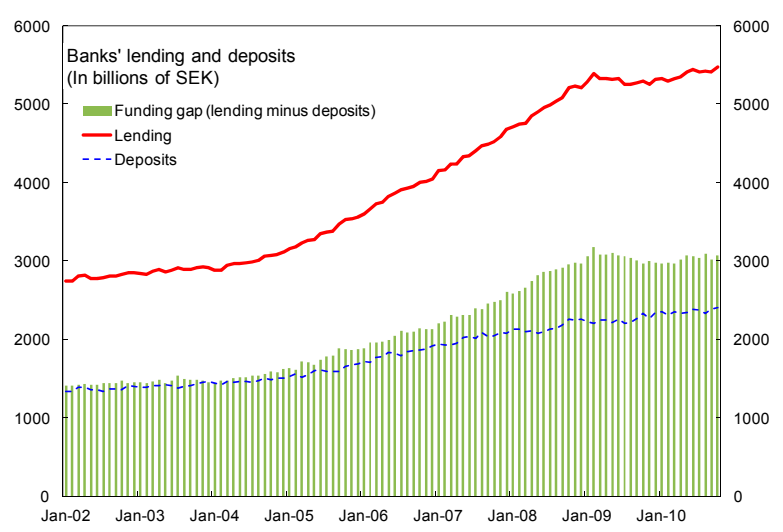

Although their holding of liquidity assets is comparable with European peers...

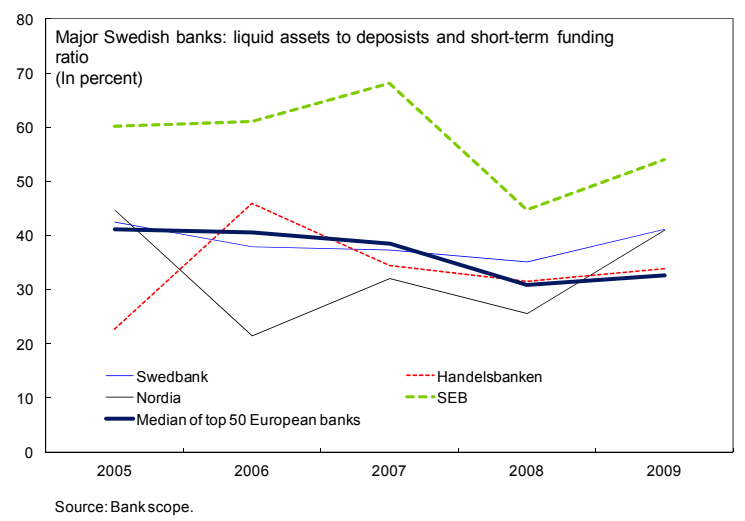

Funding gap positions are wide particularly in U.S. dollars.

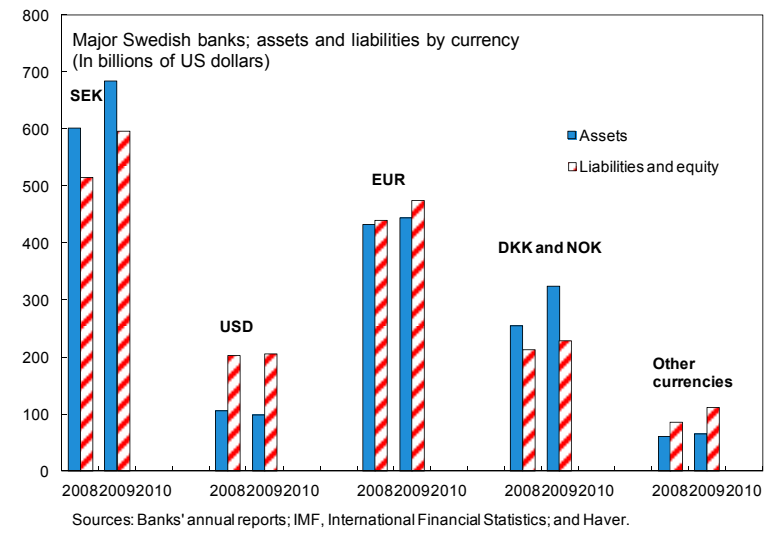

...with increased reliance on wholesale funding.

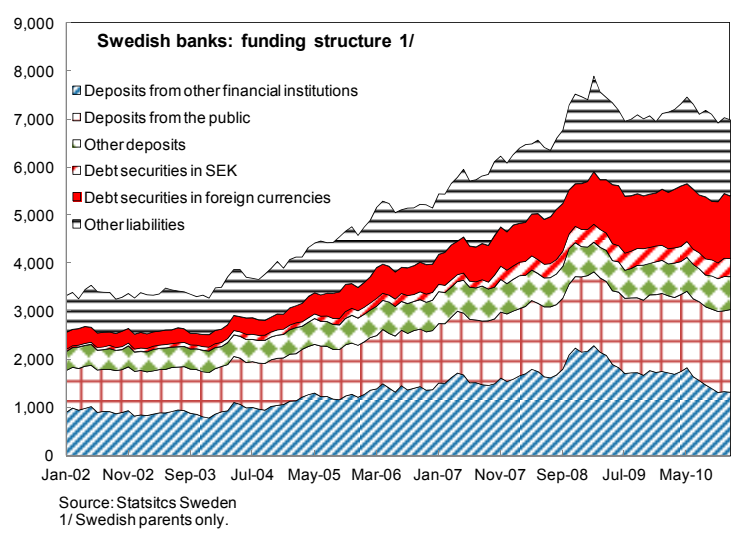

...Swedish banks' reliance on wholesale funding exceeds European peers.

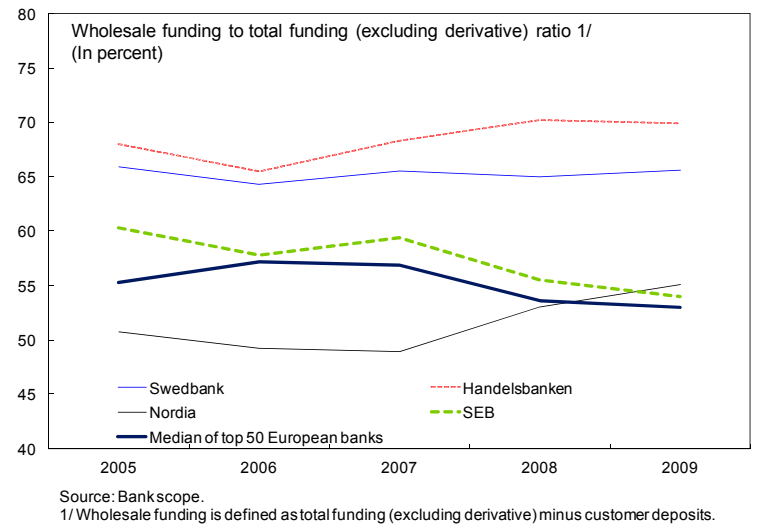

In the middle of the global financial crisis, rollover risks were recognized.

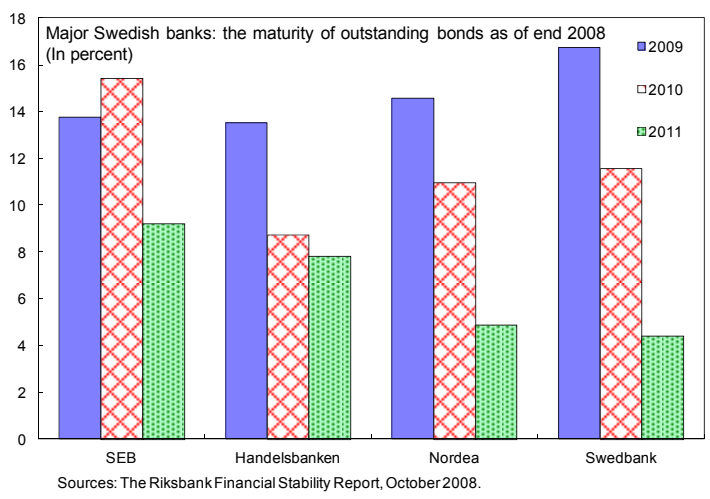


8. The indicative decomposition of the interbank risk premium shows a major shift in the type of risk (Figure 2). Through 2007-08, an increase in the risk premium was primarily driven by a liquidity risk premium, as marketbased credit risk indicators remained low.

However, when the depth and width of the global crisis were recognized in late 2008 and investors' concern about Swedish banks' exposure in the Baltics was heightened, the credit risk premium became the main driver of the whole risk premium (see Soultanaeva and Strömqvist, 2009).

In response, the authorities implemented unprecedented liquidity easing measures

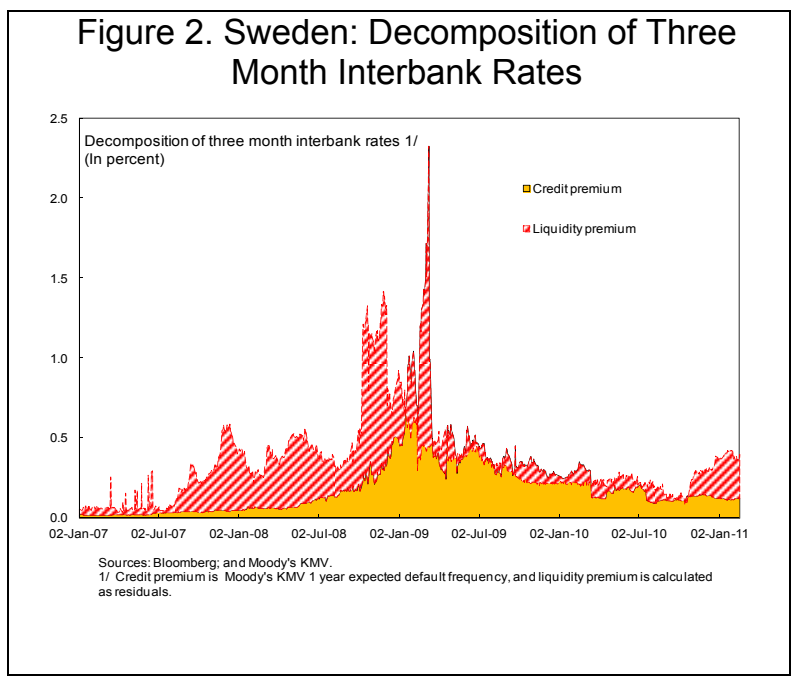

9. The crisis-response measures undertaken by the authorities largely resembled those by other advanced economies.

- $\quad$ The Riksbank implemented a sweep of new liquidity measures, such as the expansion of eligible collateral and counterparties, longer term repo operations with a variable and fixed term interest rate, a longer term U.S. dollar credit facility, and a new credit facility with commercial papers as collateral (Table 1).

- $\quad$ The National Debt Office (NDO) borrowed externally SEK 100 billion (US\$15 billion) to boost international reserves, while the Riksbank tapped U.S. Federal Reserve and European Central Bank (ECB)'s currency swap arrangements. Also, the NDO issued treasury bills, beyond its scheduled funding plan, to meet increased demand for treasury securities and invested the funds raised in covered bonds to boost covered (mortgage) bond market.

- The government raised the deposit guarantee from SEK 250,000 to SEK 500,000 and to include all types of deposits. The government approved a debt guarantee scheme for the medium-term borrowing ( 3 months -5 years) of banks and mortgage institutions. These measures helped to stabilize banks' funding conditions.

\section{As a result of aggressive liquidity provisions, the size of the Riksbank's balance} sheet ballooned (Figure 3). Together with the government's bank debt guarantee scheme, the size of the authorities liquidity support reached nearly 8 percent of the total funding of banks at the peak of funding market stress (Figure 4). 


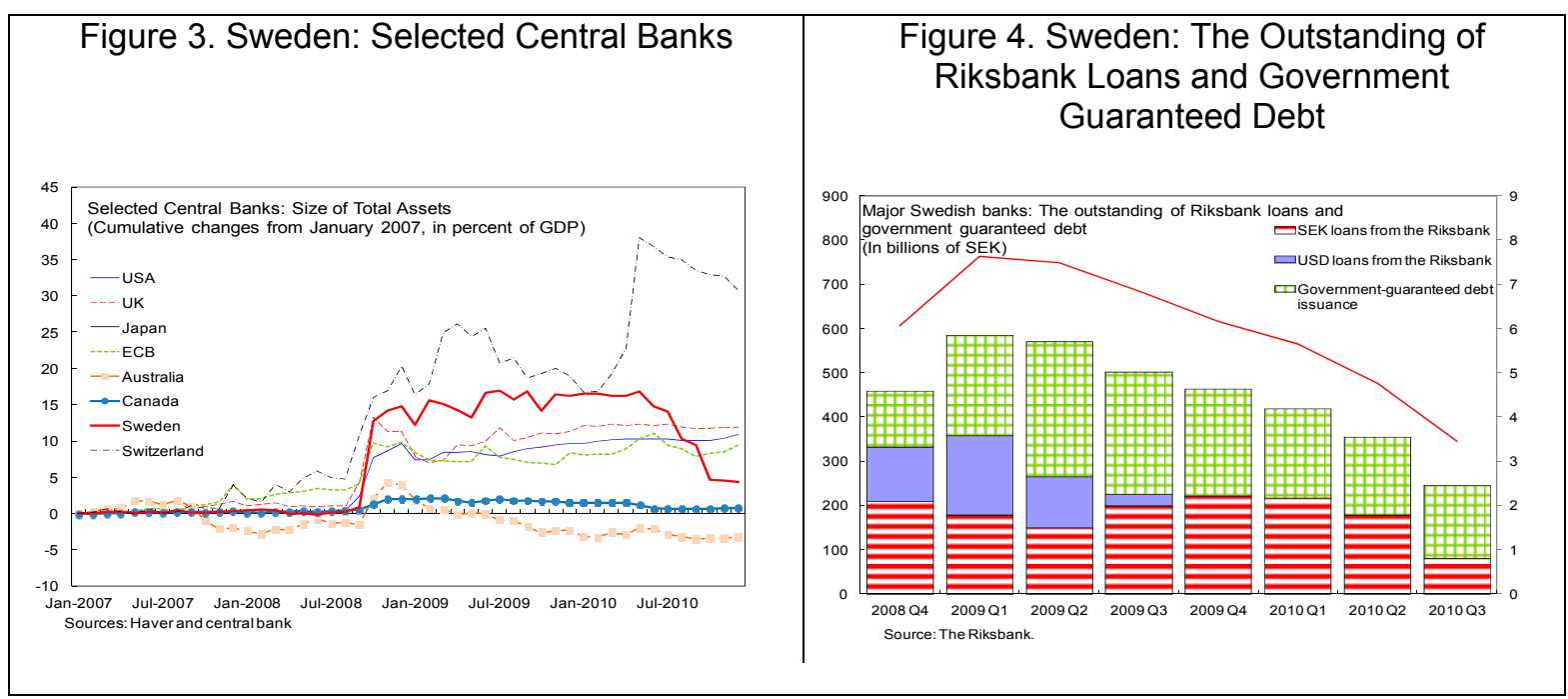

11. The liquidity risk premium in Sweden's interbank market started declining in the spring of 2009, and exit from these stabilization measures is now underway. The Riksbank's liquidity measures were modified to include incentives - such as penal interest rates - to discourage banks from using these facilities once market conditions normalized. The Riksbank terminated its U.S. dollar lending facility by end-2009, as funding conditions had improved and demand for the facility had diminished. In addition, the Riksbank phased out longer term kroner operations, beginning with the longest operations, and raised penal rates to discourage their use. By the autumn of 2010, the Riksbank had exited from all unconventional liquidity measures. The Riksbank now maintains a high level of international reserves, and the government continues to maintain the guarantee scheme, though currently no banks are participating in this program.

\section{Although the authorities' response was successful, there are merits in reviewing the exiting liquidity risk management framework}

\section{The authorities' response has been effective in containing strains in financial}

markets. Nevertheless, the crisis revealed several weaknesses in Sweden's liquidity risk management framework as follows.

- $\quad$ Sweden did not have an effective liquidity regulatory and reporting framework, partly because pre crisis, systemic liquidity risks were not well recognized (see Section IIII B).

- $\quad$ The Riksbank's foreign exchange liquidity support proved effective. However, the experience of the crisis presented the ambiguity in the institutional arrangements for international reserve management (see Section III C).

- In normal times, the Riksbank conducts limited liquidity operations to encourage markets to fully function and thus, its balance sheet is small and very lean. During the crisis, the Riksbank was quick to adjust its balance sheet and implement various new liquidity operations, similar to other advanced economy central banks. However, it faced one constraint, namely the lack of ability to implement a term treasury securities lending facility (see Section III D). 
Table 1. Sweden: Selected Economies: Central Banks' Liquidity Strain Easing Measures ${ }^{1}$

\begin{tabular}{|c|c|c|c|c|c|c|c|c|}
\hline & AUS & CAN & Euro & JPN & UK & USA & & Sweden \\
\hline $\begin{array}{l}\text { Long-term repo } \\
\text { operations }\end{array}$ & $\sqrt{ }$ & $\sqrt{ }$ & $\sqrt{ }$ & $\sqrt{ }$ & $\sqrt{ }$ & $\sqrt{ }$ & $\sqrt{ }$ & $\begin{array}{l}\text { The Riksbank introduced new } 3,6 \text {, and } 12 \text {-month } \\
\text { term loan facilities to facilitate banks' access to } \\
\text { longer term funds. }\end{array}$ \\
\hline Expansion of collateral & $\sqrt{ }$ & $\sqrt{ }$ & $\sqrt{ }$ & $\sqrt{ }$ & & $\sqrt{ }$ & $\sqrt{ }$ & $\begin{array}{l}\text { The Riksbank accepted covered bonds and } \\
\text { commercial paper as collateral and lowered the } \\
\text { minimum credit rating requirements for long-term } \\
\text { securities pledged as collateral. }\end{array}$ \\
\hline $\begin{array}{l}\text { Longer term securities } \\
\text { lending operations }\end{array}$ & & & & $\sqrt{ }$ & $\sqrt{ }$ & $\sqrt{ }$ & & \\
\hline Broader counterparties & & $\sqrt{ }$ & $\sqrt{ }$ & & & $\sqrt{ }$ & $\sqrt{ }$ & $\begin{array}{l}\text { The Riksbank increased the number of monetary } \\
\text { policy counterparties (restricted counterparties) by } \\
\text { allowing more financial institutions to have access to } \\
\text { some of its liquidity facilities. }\end{array}$ \\
\hline $\begin{array}{l}\text { Outright purchase of } \\
\text { public sector securities }\end{array}$ & & & & $\sqrt{ }$ & $\sqrt{ }$ & $\sqrt{ }$ & & \\
\hline $\begin{array}{l}\text { Outright purchase of } \\
\text { private sector securities }\end{array}$ & & & $\sqrt{ }$ & $\sqrt{ }$ & $\sqrt{ }$ & $\sqrt{ }$ & & \\
\hline $\begin{array}{l}\text { Foreign currency repo } \\
\text { operations }\end{array}$ & $\sqrt{ }$ & & $\sqrt{ }$ & $\sqrt{ }$ & $\sqrt{ }$ & & $\sqrt{ }$ & $\begin{array}{l}\text { The Riksbank introduced new } 28 \text { and 84-day dollar } \\
\text { term loan facilities. }\end{array}$ \\
\hline Foreign exchange swap & $\sqrt{ }$ & $\sqrt{ }$ & $\sqrt{ }$ & $\sqrt{ }$ & $\sqrt{ }$ & $\sqrt{ }$ & $\sqrt{ }$ & $\begin{array}{l}\text { The Riksbank and U.S. Fed set up temporary } \\
\text { reciprocal swap facilities ( } \$ 30 \text { billion). A separate } \\
\text { swap facility was also established with the ECB. }\end{array}$ \\
\hline
\end{tabular}

${ }^{1}$ AUS, CAN, Euro, and JPN refer to Australia, Canada, the Euro area, and Japan, respectively. 


\section{STREngthening The SYSTEMIC LiQUidity RiSk MANAGEMENT FraMEWORK}

\section{A. The Framework}

\section{This note takes a stand that robust liquidity risk management entails the} following four pillars: (i) a sound regulatory framework; (ii) an effective central bank liquidity toolkit; (iii) the government's ability to provide liquidity support measures; and (iv) an efficient payment and settlement system. ${ }^{3}$

- $\quad$ Regulatory framework. The primary responsibility for liquidity risk management should rest with individual banks. A bank should establish a robust liquidity risk management framework that ensures the maintenance of sufficient liquidity to withstand a range of stress events. Supervisors should assess the adequacy of both banks' liquidity risk management frameworks and their liquidity positions, and should take prompt action if a bank is deficient in either area in order to protect depositors and to limit potential damage to the financial system. ${ }^{4}$

- Central bank liquidity toolkit. In the event of a systemic liquidity shortage (i.e., an abnormal increase in demand for central bank money), it is the central banks that are able to ultimately solve the shortage, given their monopoly power of issuing central bank money. Central banks can also affect liquidity conditions in broader segments of financial markets, beyond central bank money markets, such as foreign exchange markets and treasury securities markets. However, their ability to undertake operations in these markets is often constrained by the structure of their balance sheets. For example, central banks cannot create foreign currencies for the use of foreign currency lending operations or influence liquidity in treasury securities markets if they do not hold these securities in their balance sheet.

- Government liquidity support measures. In normal times, the government's role in liquidity risk management is inconspicuous, with the important exception of maintaining deposit insurance management. In stress times, deposit insurance and a government debt guarantee program can play a critical role in sustaining confidence in the financial system. However, the government's ability to support the financial system hinges largely on its strength in public finance, as bank support measures raise the government's direct or indirect liabilities.

\footnotetext{
${ }^{3}$ See relevant discussions in IMF, 2010b and the Bank of Japan, 2009.

${ }^{4}$ Basel Committee on Banking and Supervision, Principles for Sound Liquidity Risk Management and Supervision, Principle 1.
} 
- Infrastructure. The efficiency and safety of the payment and settlement system is important to minimize liquidity risks in the financial system. For example, the amount of central bank money needed for payment partly depends on the speed of the settlement system and the availability of an intraday overdraft facility.

\begin{tabular}{|c|c|c|c|}
\hline \multicolumn{4}{|c|}{ Sweden: Sound Systemic Liquidity Risk Management } \\
\hline $\begin{array}{l}\qquad \text { Banks } \\
\text { - Liquidity risk } \\
\text { management } \\
\text { Regulators and } \\
\text { supervisors } \\
\text { - Liquidity risk } \\
\text { monitoring and } \\
\text { supervision } \\
\text { - Prudential regulations }\end{array}$ & $\begin{array}{l}\text { The central bank } \\
\text { - Liquidity and liquidity } \\
\text { risk monitoring } \\
\text { - Liquidity operations }\end{array}$ & $\begin{array}{l}\text { Government } \\
\text { - Bank debt guarantees } \\
\text { - Deposit insurance }\end{array}$ & $\begin{array}{l}\text { Infrastructure } \\
\text { - Payment and } \\
\text { settlement system }\end{array}$ \\
\hline
\end{tabular}

14. These four elements serve complementary and synergistic roles. The stronger each of the four elements is, the greater will be the resilience of the financial system to cope with liquidity risk. This also implies that, conceptually, a weakness in one element should be compensated by additional strength in the remaining elements. For example, on banks' wholesale funding risk in foreign exchange currencies, if the central bank's ability to provide foreign currency liquidity is limited, prudential regulations and supervision on funding risks should be stronger, and also the government's support capacity, so as to compensate for this weakness.

\section{A challenge is how to allocate liquidity insurance between the private and public sectors.}

15. An important policy question is how to achieve the right balance of responsibility for liquidity risk management and insurance between the public and private sectors. The private sector does not necessarily have a strong incentive to pay costs for liquidity insurance, including costs for externality. Thus, regulations are required to ensure that the private sector takes adequate responsibility, the central bank and the government have adequate capacity and tools to backstop liquidity risks, and there needs sound infrastructure. Of these issues, the remainder of this section focuses on the following three areas: (i) liquidity regulation; (ii) the framework for foreign exchange liquidity support; and (iii) the Riksbank's domestic liquidity toolkit. 


\section{B. Liquidity Regulation}

\section{The liquidity regulation was inadequate}

\section{Prior to the global crisis, the Financial Supervisory Authority (FSA)'s} regulatory policy on liquidity risk management was mainly based on the following two regulations.

- “General Guidelines Governing Management of Market and Liquidity Risks in Credit Institutions and Investment Firms" (FFFS 2000:10). ${ }^{5}$

The purpose of these guidelines is to "promote professional management of market and liquidity risks in credit institutions and investment firms." These guidelines set the general norm of risk measurement and valuation, reporting, and risk control on market and liquidity risks. ${ }^{6}$

- "Regulations Regarding Reporting of Liquidity Risk" (FFFS 2007:3 and amendments FFFS 2008:3).

The regulations require financial institutions to report (i) cash flow forecasts for various durations up to 12 months, including expected liquidity asset positions and funding; and (ii) the outstanding liabilities (both interbank market and money market borrowings) in Swedish kroner and foreign currencies, as well as funding concentration indicators (total outstanding gross liability to its five largest lenders and the amount due to its largest lenders). Financial institutions were required to submit the report four times a year at the end of every quarter, with a one month lag.

17. However, as elsewhere in European economies, these regulations were not adequate to maintain banks' resilience against liquidity shocks. Furthermore, the reporting framework - quarterly reporting with one month lag — proved unsatisfactory when the authorities needed timely information to handle acute and quickly evolving financial shocks.

\section{New liquidity regulations are appropriately being implemented}

18. The authorities have begun to review the regulatory framework on liquidity risk management. In December 2010, the FSA adopted a new regulation on "Management of Liquidity Risks in Credit Institutions and Investment Firms" (FFFS 2010:7), which embeds the main elements of the Basel Committee's "Principles for Sound Liquidity Risk Management and Oversight (September 2008). The new regulations require financial

\footnotetext{
${ }^{5}$ See http://www.fi.se/Folder-EN/Startpage/Regulations/Regulatory-Code/FFFS-200010/.

${ }^{6}$ See http://www.fi.se/Folder-EN/Startpage/Regulations/Regulatory-Code/FFFS-20073/.
} 
institutions to establish a proper governance framework for liquidity risk management (Box 1).

\section{Box 1. Regulation on Management of Liquidity Risks in Credit Institutions and Investment Firms (FFFS 2010:7)}

The key elements of the new regulation are as follows.

- A financial institution should have guidelines and instructions for managing its liquidity risk in accordance with the risk tolerance to ensure that the firm has sufficient liquidity.

- A financial institution should have a central function for the independent control of liquidity risk (liquidity risk control) which reports to the managing director or a member of senior management.

- A financial institution should be able to quantify its liquidity risks and regularly conduct stress tests based on its own risk profile.

- A financial institution should establish a long-term funding strategy, manage intraday liquidity positions, liquidity reserves, and collateral, and establish a contingency plan.

19. The FSA is also planning to introduce a new comprehensive liquidity reporting framework in July 2011. Test reporting already began in September 2010. The regulation will apply to credit institutions and securities companies that have total assets of over SEK 5 billion (45 institutions). It covers detailed information on liquidity reserves, cash flows, funding, and derivatives by currency, and banks will be required to submit the report on a monthly basis within a 15-day lag. To enhance the monitoring of the short-term resilience of their liquidity risk profile, financial institutions will also be required to report the Liquidity Coverage Ratio (LCR) by major currencies (Swedish kroner, euro, and U.S. dollar) in line with the Basel III agreement.

20. The next steps should include the implementation of other elements of the Basel III liquidity regulatory standards. First, the LCR should become part of Pillar III disclosure requirements once the implications have been evaluated. Second, to ensure resilience over a longer time horizon, a Net Stable Funding Ratio (NSFR) should be developed. The authorities are considering moving forward in this direction.

\section{Both LCR and NSFR should be well calibrated to contribute to financial} stability on the one hand and not to overly restrict maturity transformation of financial activities on the other. The quantitative regulations - if too restrictively imposed without due consideration to their impact — could lead to unintended consequences, such as leakages of financial activities to less regulated entities and distortion in some segments of the financial markets. The calibration of standardized quantitative regulations across all types of financial institutions will be challenging, particularly given that each of the major Swedish banks has a unique and diversified business model (Box 2). 


\section{The Framework for Foreign Exchange Liquidity Support}

\section{The foreign currency liquidity support policy should be reviewed}

\section{The Riksbank's dollar lending facility was effective in easing banks' funding}

strains. This facility was supported by (i) bilateral temporary reciprocal swap facilities with the Federal Reserve and ECB; and (ii) international reserves. However, the crisis revealed the following gaps in the existing framework.

- $\quad$ Potential institutional conflict. Currently, the NDO is fully in charge of external borrowing. Thus, while the Riksbank has the statutory mandate to manage international reserves, a decision to raise international reserves through external borrowing should in practice be determined jointly with the NDO. However, tension would arise if the Riksbank and the NDO had different opinions about the appropriate level of international reserves.

\section{Box 2. Major Swedish Banks-Unique and Diversified Business Models}

- $\quad$ Nordea is the largest bank, with its total assets equivalent to 1.7 times Sweden's GDP. It operates evenly in the whole Nordic region. The Swedish government holds 13.6 percent of Nordea shares.

- Handelsbanken has the largest market share in Sweden. It has large retail mortgage lending operations (36 percent of total exposures), with high dependence on debt securities financing (47 percent of total liabilities). The leverage ratio is the lowest (3.6) among the four major banks.

- $\quad$ SEB has comparative strength in corporate banking: corporate sector lending accounts for 64 percent of total exposures, while retail mortgage lending is only 28 percent. SEB's strategic focus includes investment banking and wealth management, and fees and commissions compose a substantial portion of income sources.

- $\quad$ Swedbank focuses on retail mortgages (54 percent of total exposures) with significant reliance on debt securities financing (42 percent of total liabilities). Its operations in the Baltics, while being scaled down, remain substantial (11 percent of total exposures).
Major Swedish banks: selected indicators

\begin{tabular}{|c|c|c|c|c|}
\hline & Nordea & $\begin{array}{l}\text { Handels- } \\
\text { banken }\end{array}$ & SEB & $\begin{array}{r}\text { Swed- } \\
\text { bank }\end{array}$ \\
\hline Total assets (in billions of $\mathrm{SKr}$ ) & 5,361 & 2,154 & 2,180 & 1,716 \\
\hline In percent of GDP & 168.3 & 67.6 & 68.4 & 53.8 \\
\hline \multicolumn{5}{|l|}{ Share of total exposures (percent) } \\
\hline Retail mortgage & 30.8 & 35.8 & 28.3 & 53.8 \\
\hline Other retails & 10.3 & 9.7 & 7.5 & 3.5 \\
\hline Corporate & 58.9 & 54.4 & 64.2 & 42.7 \\
\hline \multicolumn{5}{|l|}{ Share of total liabilities (percent) } \\
\hline Deposits from the public & 31.7 & 26.4 & 34.2 & 33.0 \\
\hline Debt securities & 27.2 & 46.7 & 25.5 & 42.4 \\
\hline Others & 41.0 & 26.9 & 40.3 & 24.7 \\
\hline \multicolumn{5}{|l|}{ Share of operating income (percent) } \\
\hline Net interest income & 55.3 & 68.2 & 43.4 & 52.6 \\
\hline Net fees and commissions & 23.1 & 25.6 & 38.4 & 30.7 \\
\hline Others & 21.6 & 6.2 & 18.2 & 16.7 \\
\hline $\begin{array}{l}\text { Share of investment portfolio } \\
\text { (excl. govt bonds) in total assets }\end{array}$ & 10.0 & 6.0 & 16.0 & 5.0 \\
\hline \multicolumn{5}{|c|}{ Share of geographical exposures (percent) } \\
\hline Sweden & 27.1 & 70.9 & 64.9 & 85.3 \\
\hline Other Nordic & 63.9 & 17.6 & 5.7 & 2.1 \\
\hline Baltic & 1.8 & 0.0 & 8.7 & 11.4 \\
\hline Others & 7.3 & 11.5 & 20.7 & 1.2 \\
\hline \multicolumn{5}{|l|}{ Capital and rating } \\
\hline Tier 1 capital ratio (percent) & 9.8 & 9.2 & 12.8 & 11.0 \\
\hline Tier 1 leverage ratio (percent) & 4.0 & 3.6 & 4.3 & 4.6 \\
\hline Credit rating (S\&P long term) & AA- & AA- & A & A \\
\hline
\end{tabular}

Sources: Banks' annual reports; and SNL Financial database. 
- Inadequacy of international reserves. Before the crisis, the Swedish authorities, like other advanced economy policymakers, assumed that there was virtually no precautionary reason to hold international reserves, because Sweden would have access to markets even under adverse conditions. However, at the peak of the crisis (April 2009), demand for the Riksbank's dollar lending reached $\$ 30$ billion, equivalent to the level of international reserves prior to the crisis $(\$ 29.7$ billion as of end-2008). Thus, the authorities tapped the Federal Reserve's swap facility (drawing nearly $\$ 25$ billion) and also borrowed externally (about $\$ 15$ billion) to boost international reserves. While it is not easy to determine the right level of international reserves, this issue requires further attention.

- Uncertainty regarding swap facilities. The swap facility with the Federal Reserve proved invaluable during the crisis, but it may not be always available in the future. In December 2008, the Federal Reserve decided to establish a reciprocal swap facility with the Riksbank and several other central banks, and then terminated it in January 2010. However, when the Federal Reserve subsequently reopened the swap facility in May 2010, the Riksbank was no longer included in the list of the Federal Reserve's counterparties. If the Federal Reserve's swap facility had not been available during the crisis, Sweden would have had to use all of its international reserves for the Riksbank's dollar lending facility.

The governance arrangement on international reserve management should be clarified

23. International practice varies on who manages international reserves (Box 3 ). In a number of economies, the central bank is the principal owner of the foreign exchange reserves and manages these as part of their own balance sheet. But in several economies, international reserves are managed and owned solely by the government (Japan and the United States). Also hybrid arrangements exist: for example, in Canada and the United Kingdom, the foreign exchange reserves are owned by the government and managed under an agency agreement by the central bank.

24. In Sweden, the statutory responsibility of international reserve management appears to have been clearly established. Sveriges Riksbank Act (Riksbank Act) mandates the Riksbank to manage international reserves (Chapter 7, Article 2.). It also allows the Riksbank to issue foreign currency debts. Meanwhile the Budget Act (2011:203) allows the NDO to borrow externally on behalf of the Riksbank at the expense of the Riksbank.

25. However, in practice, the NDO would agree to borrow externally only if it judges the merits of additional external funding from public asset and liability management perspectives. As such, a risk of coordination problems could potentially emerge because each institution, the Riksbank and the NDO, has different motives in considering the appropriate level of international reserves. The Riksbank's primary motivation is financial stability, and to this end, may need to hold sufficient precautionary international reserves to 
implement foreign currency lending operations flexibly and timely during market stress times, whereas as a debt manager, the NDO's motivations include the efficiency in public finance management.

\section{Box 3. International Practice: Arrangements for International Reserve Management}

No international "best" practice exists and practices differ widely. ${ }^{7}$ The central bank laws often state that "the Bank will hold and manage the official foreign reserves," but actual practices on how international reserve is managed differ across economies.

- In the vast majority of economies, the central bank, or monetary authority, is the principal owner of the foreign exchange reserves and manages these as part of its own balance sheet.

- In Japan and the United States, the foreign exchange reserves are owned and managed solely by the government, namely by: (i) Ministry of Finance in Japan; and (ii) U.S. Treasury in the United States.

- In Canada and the United Kingdom, the foreign exchange reserves are owned by the government and managed under an agency agreement by the central bank: (i) in Canada, the reserves are owned by the government and managed jointly between the Bank of Canada and the Department of Finance; and (ii) in the United Kingdom, HM Treasury owns the foreign exchange reserves, which are managed by the Bank of England in accordance with the annual remit.

- In New Zealand, the Reserve Bank of New Zealand's foreign exchange reserves are funded by a foreign currency loan from the Treasury. Thus, formally the central bank owns and manages the reserves but also has a loan of the same size, insulating it from balance sheet risk, while having a full legal say on its use.

- $\quad$ In South Korea, the Bank of Korea (BoK) holds and manages the foreign exchange reserves jointly with the Ministry of Finance and Economy (MoFE). The BoK and MoFE have joint ownership of the reserves.

\section{Table 3 summarizes the pros and cons of three alternative approaches in reviewing the institutional setup for international reserve management.}

- The Riksbank purchases international reserve assets. This would give the Riksbank effective discretionary power to boost international reserves. However, this requires a clear delineation from foreign exchange intervention to maintain the free floating exchange arrangement. Also, the Riksbank's capital position may need to be raised as currency mismatch and financial risks would rise.

- The Riksbank issues foreign currency debts. This will not lead to currency mismatches. However, this approach will require a debt management coordination mechanism with the NDO as central bank foreign currency securities could compete with government securities.

\footnotetext{
${ }^{7}$ See general principles in The Guidelines for Exchange Reserve Management (2001, IMF).
} 
- A formal coordination mechanism is established. This could be the most suitable approach for Sweden, as it would not require a substantial overhaul of the existing institutional setup. The international reserve management policy could be included in the mandate of a high level Systemic Financial Stability Council, a macroprudential policy institution, the establishment of which is being proposed in the FSAP Update.

Table 2. Sweden: Alternative Approaches in Reviewing International Reserve Management

\begin{tabular}{|l|l|l|l|}
\hline Approach I & Approach II & \multicolumn{1}{c|}{ Approach III } \\
\cline { 2 - 5 } & $\begin{array}{l}\text { The Riksbank purchases } \\
\text { foreign assets on its own }\end{array}$ & $\begin{array}{c}\text { The Riksbank issues foreign } \\
\text { currency debts }\end{array}$ & $\begin{array}{c}\text { A formal coordination } \\
\text { framework is established }\end{array}$ \\
\hline Pros & $\begin{array}{l}\text { - The Riksbank can decide on } \\
\text { the level of international } \\
\text { reserves on its own decision } \\
\text { and discretion. }\end{array}$ & $\begin{array}{l}\text { - The Riksbank can decide } \\
\text { on the level of international } \\
\text { reserves on its own } \\
\text { decision and discretion. } \\
\text { Cons }\end{array}$ & $\begin{array}{l}\text { - No substantial overhaul } \\
\text { of the existing } \\
\text { institutional set up is } \\
\text { required. }\end{array}$ \\
\hline be eliminated \\
$\begin{array}{l}\text { - Costs arising from currency } \\
\text { mismatches could be high. } \\
\text { To address larger financial } \\
\text { risks, the Riksbank needs to } \\
\text { hold more capital in its } \\
\text { balance sheet }\end{array}$ & $\begin{array}{l}\text { - A public debt coordination } \\
\text { mechanism is needed. }\end{array}$ & $\begin{array}{l}\text { - An effective coordination } \\
\text { mechanism should be in } \\
\text { place. }\end{array}$ \\
\hline
\end{tabular}

\section{The Riksbank's Domestic Liquidity Management Framework}

\section{In normal times, the Riksbank's balance sheet is relatively small and lean} compared to other advanced economy central banks. For example, prior to the crisis, the size of the Riksbank's balance sheet was $6 \frac{1}{2}$ percent of GDP, much smaller than the size of the balance sheet of the ECB, the National Bank of Denmark, the Swiss National Bank, and the Bank of Japan (Figure 5). The structure of the Riksbank's balance sheet was also unique: it comprised mostly foreign assets and did not hold public securities, whereas other central banks, such as the Federal Reserve, Bank of England, and Bank of Canada regularly conducted outright purchase of public securities and thus held them in their balance sheets (Figure 6). 


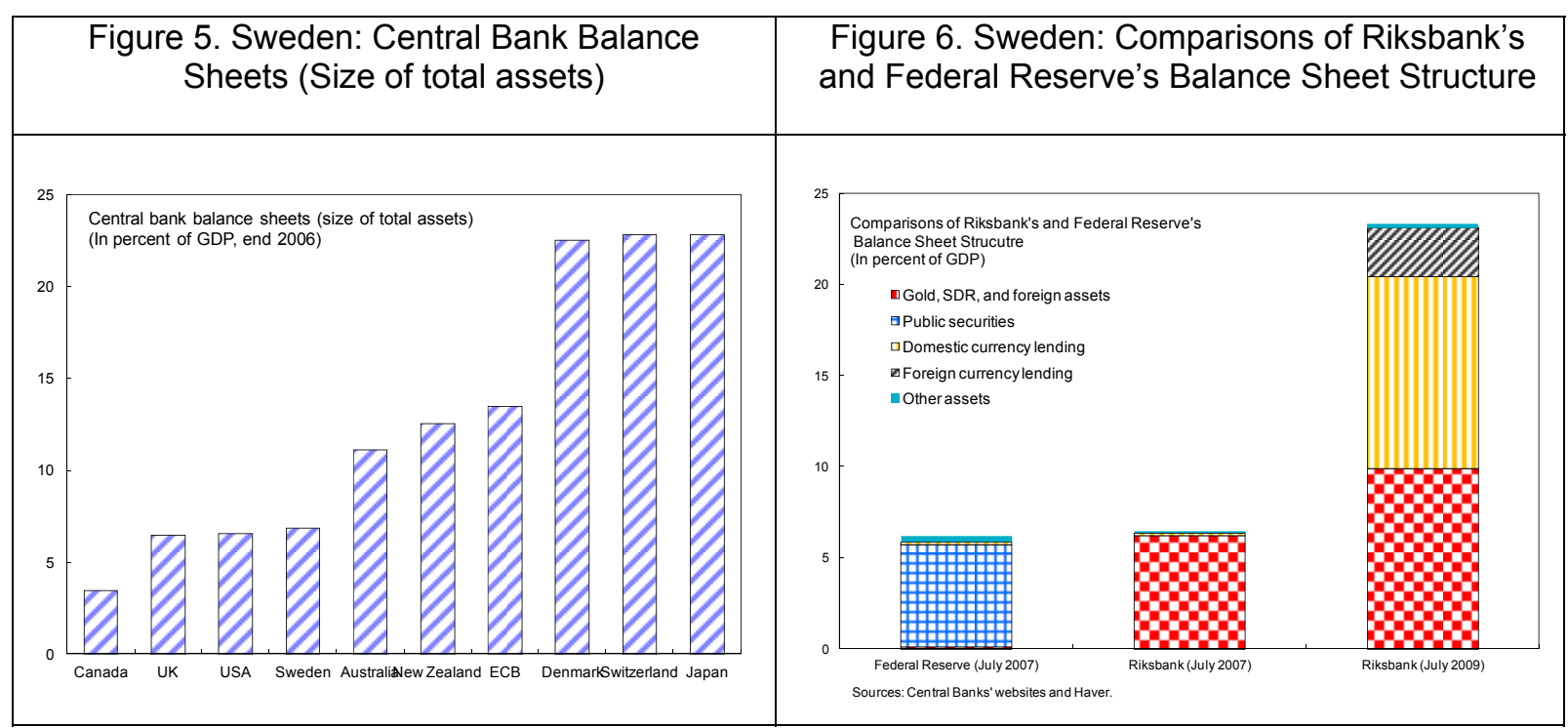

28. The smallness and leanness of the Riksbank's balance sheet reflect its particular style in conducting market liquidity operations. To maximize financial institutions' incentives to manage their liquidity on their own, the Riksbank attempts to minimize its operations in the market. ${ }^{8}$ The Riksbank neither conducts outright repo operations nor has reserve requirements.

The Riksbank's domestic liquidity management framework has worked effectively but could be further refined.

\section{During the crisis, the Riksbank was quick to adjust the operational framework} to meet the increased demand for central bank money. However, it faced one constraint, namely the lack of ability to implement a term treasury securities lending facility-lending treasury securities to banks in exchange for other marketable financial instruments (e.g., mortgage backed securities). ${ }^{9}$ Several advanced economy central banks introduced a term treasury securities lending facility (e.g., the Federal Reserve's Term Securities Lending Facility and the Bank of England's Special Liquidity scheme), as part of their crisis response liquidity measures (see Table 1). In Sweden, because the Riksbank did not hold treasury

\footnotetext{
${ }^{8}$ The Riksbank's operational framework is based on a corridor framework, and the Riksbank conducts its main market operations, either by repurchase operations (for liquidity supply) or the issuance of Riksbank certificates (for liquidity mop-up), once a week. To better guide overnight interest rates close to the repo rate, the Riksbank also conducts fine-tuning operations on a daily basis, by offering credits or taking deposits at an interest rate equal to the report rate plus/minus 0.1 percentage points.

${ }^{9}$ A merit of treasury securities lending facility is that the central bank is able to support liquidity in the financing markets for treasury securities and other assets in stress times without directly affecting reserve money.
} 
securities in its balance sheet, the NDO issued additional treasury securities beyond its budgetary need to replicate what those other central banks did.

30. There are merits in introducing a term treasury securities lending facility as part of the Riksbank's own liquidity toolkit. In establishing a treasury securities lending facility, there is no need for the Riksbank to hold treasury securities in its balance sheet. As an option, the Riksbank could introduce an outright securities purchase facility to build up the holding of these securities. However, this would not be compatible with the current operational framework, because in normal times, the outright purchase of treasury securities may need to be combined with mopping-up operations under a zero-reserve requirements framework.

\section{Alternatively, the NDO could facilitate the functioning of this facility by lending} treasury securities to the Riksbank when required. This could be a more efficient and effective arrangement than what Sweden did during the crisis (the NDO's issuance of additional treasury securities), as the treasury security lending facility would be most effective if used as a complement to the Riksbank's other market operations. An MOU may be needed to formalize this arrangement. Furthermore, once introduced, it is important that this new facility be tested in normal times to enhance the operational familiarity of market participants. ${ }^{10}$

\footnotetext{
${ }^{10}$ This scheme should also be carefully designed not to breach the Article 101 of the Treaty Establishing the European Community that prohibits central bank financing of budget deficit. One possible approach would be that the Riksbank requires banks to return treasury securities and then returns them to the SNDO before they mature. Because cash flows (i.e., central bank money) are not involved, this transaction should not be considered as monetary financing.
} 


\section{REFERENCES}

Bank of Japan, 2009, The Bank of Japan's Approach to Liquidity Risk Management in Financial Institutions, June.

Basel Committee on Banking and Supervision, 2008, Principles for Sound Liquidity Risk Management and Supervision, September.

—_, 2010a, Basel III: International Framework for Liquidity Risk Management, Standards, and Monitoring, December.

International Monetary Fund, 2010a, "Regulating Financial Sector Outward and Inward Spillovers," in Sweden: 2010 Article IV Consultation, IMF Country Report No. 10/220, July.

—, 2010b, Global Financial Stability Report, October.

— 2011, Global Financial Stability Report, April.

Soultanaeva, Albina, and Maria Strömqvist, 2009, “The Swedish Money Market Risk Premium_Experiences from the Crisis," Riksbank Economic Review, 3/2009. 